\title{
Lacrimal Canaliculitis
}

\author{
Epaminondas de Souza Mendes Junior* \\ Escola Bahiana de Medicina e Saúde Pública, 40290-000 Salvador-Bahia, Brazil
}

Submission: May 05, 2021; Published: May 10, 2021

*Corresponding author: Epaminondas de Souza Mendes Junior, Escola Bahiana de Medicina e Saúde Pública, 40290-000 Salvador-Bahia, Brazil

\begin{abstract}
Canaliculitis is an uncommon condition of the lacrimal canaliculi. The presentation is usually unilateral and usually runs with epiphora, hyperemia, edema, and pain, with discharge of secretion by the lacrimal point. The diagnosis is clinical since its findings are quite typical. Surgical treatment with canaliculotomy has been described as the most effective. Canaliculitis should be considered in recurrent cases of conjunctivitis and the ophthalmologist should be aware of the signs for earlier management of cases.

Keywords: Canaliculitis, Canaliculotomy, Lacrimal Pathways
\end{abstract}

\section{Introduction}

Canaliculitis is an uncommon condition of lacrimal canaliculi [1-6]. It may be of primary origin due to local or secondary inflammation [1,3]. There was an increase in canaliculitis secondary to the use of plugs, due to greater use in the treatment of dry eye 7. The infectious agent most involved in the etiology of canaliculitis is Actinomyces israelii, with an increase in cases of involvement by Staphylococcus and Streptococcus [1,2]. The presentation is usually unilateral and usually runs with epiphora, hyperemia, edema, and pain, with discharge of secretion through the lacrimal point (Figures 1\&2) and the presence of concretions can be indicative of recurrent cases.
The diagnosis is clinical since its findings are quite typical. Despite this, the diagnosis is not always made quickly, leading the patient to have several assessments until a correct diagnosis is obtained. Surgical treatment with canaliculotomy (Figure 3) has been described as the most effective, but in milder cases there are reports that local irrigation with antibiotics has had good results [4]. Canaliculotomy is performed with dilation of the tear point, horizontal incision in the portion posterior canaliculus, which may or may not extend from the lacrimal point, curettage, and removal of concretions (dacryoliths), irrigation with antibiotics, whether the closure of the incision may be performed. Treatment without preservation of tear points has good functional results [7].

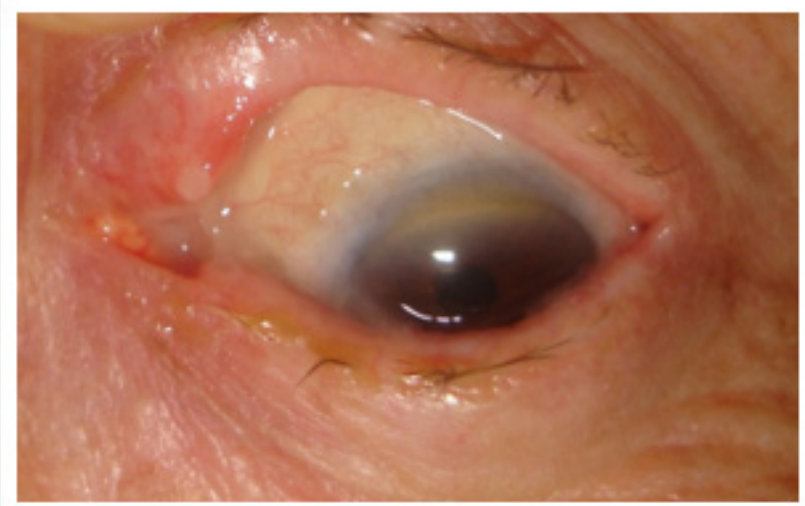

Figure 1: Upper left canaliculitis: discharge from the puctum associated with edema and local hyperemia. 


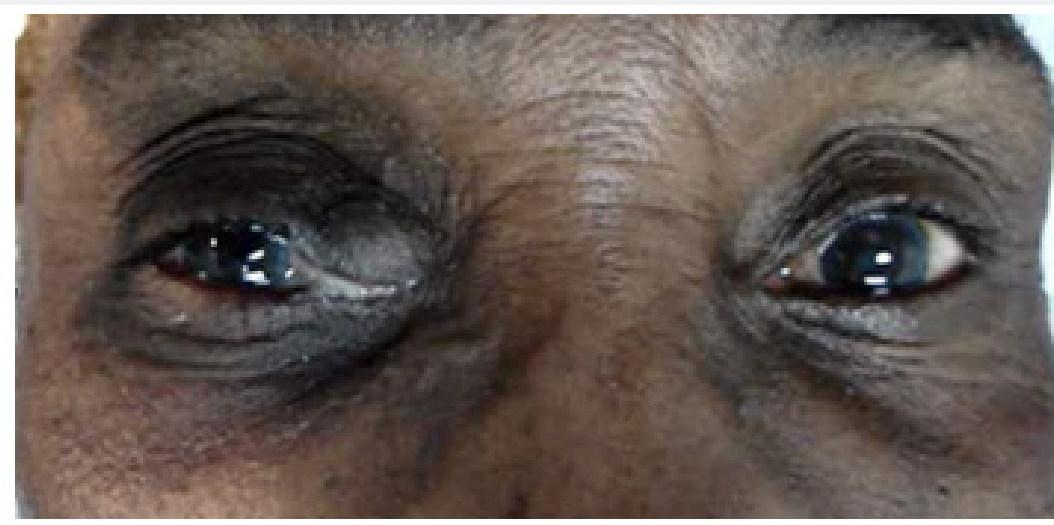

Figure 2: Upper right canaliculitis. Edema and a large amount of discharge are observed.

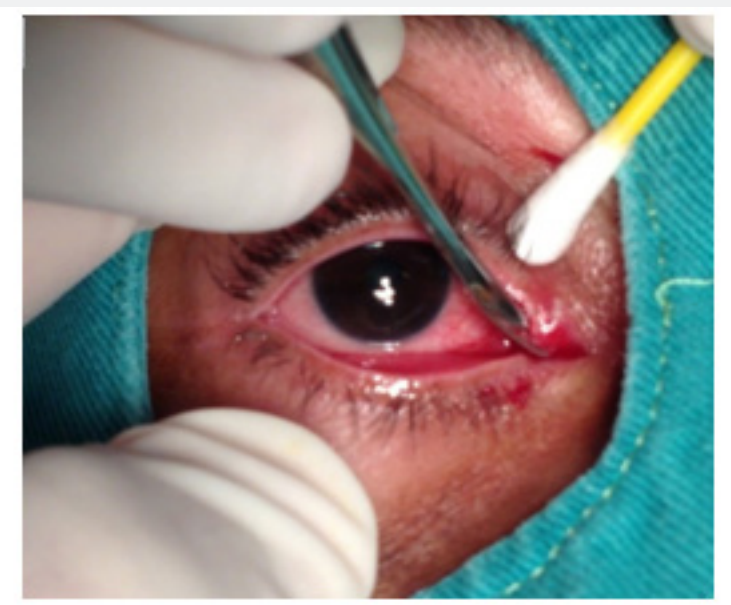

Figure 3: Incision using conjunctive scissors, in the horizontal direction of the canaliculus and including the tear point.

\section{Conclusion}

Canaliculitis should be considered in recurrent cases of conjunctivitis and the ophthalmologist should be aware of the signs for earlier management of cases.

\section{References}

1. Feroze KB, Patel BC (2021) Canaliculitis In: StatPearls [Internet] Treasure Island (FL): StatPearls Publishing;

2. Zaveri J, Cohen AJ (2014) Lacrimal canaliculitis. Saudi J Ophthalmol 28(1): 3-5.

3. Schellini SA, Sales FR, de Carvalho GM, Padovani CR (2011)
Canaliculites: apresentação de série de casos atendidos na Faculdade de Medicina de Botucatu-UNESP - com ênfase no tratamento realizado. Rev Bras Oftalmol 70(6): 400-403.

4. Marcio F, Damasceno RW, Cazorla FP, Von Faber Bison SH, Vital Filho J (2011) Canaliculite crônica supurativa - aspectos clínicos e terapêuticos: relato de 3 casos. Arq Bras Oftalmol 74(6): 441-443.

5. Balıkoğlu Yılmaz M, Şen E, Evren E, Elgin U, Yılmazbaş P (2016) Canaliculitis Awareness. Turk J Ophthalmol 46: 25-29.

6. Carneiro RC, Macedo EM, Oliveira PP (2008) Canaliculite: relato de caso e conduta. Arq Bras Oftalmol 71(1): 107-109.

7. Lee J, Flanagan JC (2001) Complications associated with silicone intracanalicular plugs. Ophthal Plast Reconstruct Surg 17(6): 465-469. 
Your next submission with Juniper Publishers will reach you the below assets

- Quality Editorial service

- Swift Peer Review

- Reprints availability

- E-prints Service

- Manuscript Podcast for convenient understanding

- Global attainment for your research

- Manuscript accessibility in different formats

( Pdf, E-pub, Full Text, Audio)

- Unceasing customer service

Track the below URL for one-step submission https://juniperpublishers.com/online-submission.php 